\title{
Does Johnson's Prescriptive Approach Still Have a Role to Play in Modern-Day Dictionaries?*
}

\author{
Rufus H. Gouws (rhg@sun.ac.za) \\ and \\ Liezl Potgieter (liezlp@vodamail.co.za),Department of Afrikaans and Dutch, \\ Stellenbosch University, Stellenbosch, South Africa
}

\begin{abstract}
Samuel Johnson's dictionary (1755) confirmed both the status of dictionaries as authoritative sources of (linguistic) knowledge and the prescriptive approach in lexicography. This approach prevailed for a long time. During the last decades the descriptive approach came to the fore, aptly supported by the increased reliance on lexicographic corpora. Modern-day lexicography has also witnessed the introduction of a third approach, i.e. the proscriptive approach, which includes features of both the prescriptive and the descriptive approach. This article investigates the occurrence of the prescriptive, descriptive and proscriptive approaches in modern-day dictionaries. A distinction is made between dictionaries focusing on language for general purposes and dictionaries focusing on languages for special purposes. It is shown that users rely on dictionaries as prescriptive reference sources and expect lexicographers to provide them with an answer to the specific question that prompted the dictionary consultation process. It is argued that knowledgeable dictionary users must be able to achieve an unambiguous retrieval of information and must be able to rely on the dictionary to satisfy their specific cognitive or communicative needs. Here the proscriptive approach plays an important role.
\end{abstract}

Keywords: COGNITIVE FUNCTION, COMMUNICATION FUNCTION, CULTUREDEPENDENT, DESCRIPTIVE, EXACT PROSCRIPTION, EXCLUSIVE PROSCRIPTION, LGP DICTIONARIES, LSP DICTIONARIES, NON-RECOMMENDED FORM, PRESCRIPTIVE, PROSCRIPTIVE, RECOMMENDATION, TYPES OF USERS, USER PERSPECTIVE.

Opsomming: Het Johnson se preskriptiewe benadering nog 'n rol te speel in moderne woordeboeke? Samuel Johnson se woordeboek (1755) het die status van woordeboeke as gesaghebbende houers van (taalkundige) kennis, maar eweneens die preskriptiewe benadering in leksikografie gevestig. Hierdie benadering het lank gegeld. Gedurende die onlangse dekades het die deskriptiewe benadering op die voorgrond getree, sterk ondersteun deur toenemende benutting van korpora. Moderne leksikografie het 'n derde benadering beleef, te wete die proskriptiewe benadering wat kenmerke van sowel die preskriptiewe as die deskriptiewe benadering bevat. Hierdie artikel ondersoek die voorkoms van die preskriptiewe, deskriptiewe en pro-

* This article is based on a paper read at the XVII Biennial Meeting of the Dictionary Society of North America, 26-30 May 2009, Indiana University, Bloomington, United States of America in a session to commemorate the tercentenary of Samuel Johnson's birth. 
skriptiewe benadering in moderne woordeboeke. 'n Onderskeid word gemaak tussen algemene en vakwoordeboeke. Daar word aangetoon dat gebruikers op woordeboeke staatmaak as preskriptiewe naslaanbronne en dit van leksikograwe verwag om aan hulle antwoorde te verskaf op die spesifieke vrae wat tot die woordeboekraadpleging aanleiding gegee het. Kundige woordeboekgebruikers moet daartoe in staat wees om 'n ondubbelsinnige ontsluiting van inligting te bereik en hulle woordeboek te kan vertrou vir die bevrediging van spesifieke kognitiewe en kommunikatiewe behoeftes. Hier speel die proskriptiewe benadering 'n wesenlike rol.

Sleutelwoorde: AANBEVELING, ALGEMENE WOORDEBOEKE, DESKRIPTIEF, EKSKLUSIEWE PROSKRIPSIE, GEBRUIKERSPERSPEKTIEF, GEBRUIKERSTIPES, KOGNITIEWE FUNKSIE, KOMMUNIKATIEWE FUNKSIE, KULTUURGEBONDE, NIE-AANBEVOLE VORM, PRESIESE PROSKRIPSIE, PRESKRIPTIEF, PROSKRIPTIEF, VAKWOORDEBOEKE

When I took the first survey of my undertaking, I found our speech copious without order, and energetick without rules: wherever I turned my view, there was perplexity to be disentangled, and confusion to be regulated; choice was to be made out of boundless variety, without any established principle of selection; adulterations were to be detected, without a settled test of purity; and modes of expression to be rejected or received, without the suffrages of any writers of classical reputation or acknowledged authority.

Samuel Johnson: Preface to A Dictionary of the English Language

\section{Introduction}

Whenever reference is made to Samuel Johnson's dictionary one of the most frequently referred to definitions is his description of a lexicographer as a harmless drudge. As a lexicographer in his own right Samuel Johnson imposed the status of a dictionary as an authoritative source of, especially, linguistic information. Looking at the ideals he set for himself in his well-known The Plan of a Dictionary of the English Language (1747) his passion for "fixing the language", the so-called "linguistic authoritarianism" puts the lexicographer in a dominant position with the potential to do both good and harm to the language. This takes the lexicographer well beyond the scope of harmless drudgery. We know that Johnson eventually realised that he could not actually achieve the fixing of the language to the extent especially other authors, e.g. Swift, originally had envisaged. Yet, the criteria according to which he selected words for inclusion as lemmata in his dictionary, the way in which he treated some of the words and the way in which he omitted certain words from his dictionary give a clear indication of a certain prescriptive approach - an approach that elevates the lexicographer to the level of being a custodian but also a judge of the language. Where such a prescriptive approach succeeds in assisting the users of a given dictionary in their quest for correct language use one can hardly object to it. However, where such an approach distorts the language by resulting in a subjective and biased presentation of data, a dictionary 
becomes a dangerous instrument. In The Plan of a Dictionary of the English Language (1747: 4) Johnson says: "It was not easy to determine by what rule of distinction the words of this dictionary were to be chosen. The chief intent of it is to preserve the purity and ascertain the meaning of our English idiom." Where the nature and extent of such a prescriptive approach impedes a dictionary to reflect the actual language use and where it can be seen as an attempt to purify the language in terms of the lexicographer's world-view, more care should be taken before adhering to such an approach.

In spite of all the legitimate criticism of a prescriptive approach and in spite of alternative approaches that might be more feasible, lexicographers should always realise that the typical dictionary user regards a dictionary, the dictionary, as an authoritative source of data from which they want to retrieve the information needed to solve those specific problems that prompted the consultation process. In some instances users may desire to rely on a dictionary that is the product of a Johnsonian approach, as stated in his Plan (Johnson 1747: 11): "one great end of this undertaking is to fix the English language." Acknowledging that this may still be the case in some instances today, this article looks at different aspects of prescriptive, descriptive and proscriptive approaches in lexicography in an attempt to find a way and to make suggestions that would meet the needs of the intended target users of a given dictionary and satisfy the genuine purpose of that dictionary. What remains nonnegotiable is the need for an approach that is scientifically based. In this regard Johnson's remark "in lexicography, as in other arts, naked science is too delicate for the purposes of life" (Johnson 1747: 4) cannot be accepted.

\section{Moving from prescriptive to descriptive}

The era following the Renaissance was characterised by dictionaries trying to open new worlds to their potential users, with the target users no longer an elite group of scholars or academics as typically seen during the medieval era but rather the average person on the street. In the words of Robert Cawdrey in his A Table Alphabeticall (1604):

A Table Alphabeticall, conteyning and teaching the true writing, and understanding of hard usual English wordes, borrowed from the Hebrew, Greeke, Latine, or French. \&c.

With the interpretation thereof by plaine English words, gathered for the benefit $\mathcal{E}$ helpe of Ladies, Gentlewomen, or any other unskilfull persons.

In 1615 William Bathe published his Ianua Linguarum (The Gate of Tongues) and this was followed in 1631 by Amos Komensky who went one step further with his Ianua Linguarum Reserata (The Gate of Tongues Unlocked). Dictionaries had to unlock the gate of tongues so that unskilful persons could gain access to knowledge. This approach helped to establish the idea of dictionaries being regarded as authoritative sources of linguistic information and Johnson's vision 
of employing his dictionary to fix the language firmly ascertained this prescriptive assignment of dictionaries. Agreement with this approach was echoed by the Lord Chesterfield, when commenting on Johnson's dictionary, saying: "Toleration, adoption and naturalization have run their lengths. Good order and authority are now necessary." Over the years different forms of prescription have developed (cf. Bergenholtz 2003) but they are usually all characterised by the lexicographer imposing his/her point of view on the user.

Many lexicographers became more Johnsonian in their prescriptive approach than Johnson himself. This often resulted in an approach characterised by efforts to purify the language, especially in multilingual environments where language contact and the subsequent language influence is an everyday reality. Such a purist approach played a major role in, for example, the early development of Afrikaans when lexicographers used their dictionaries as instruments of lexical ethnic cleansing, trying in vain to rid Afrikaans from the influence of English or, in one of the first Afrikaans dictionaries, i.e. Changuion's Proeve van Kaapsch Taaleigen (1844) where the author endeavoured to rid the then standard Dutch from the emerging Afrikaans. An important paradigm shift was introduced by Philip Gove in Webster's Third New International Dictionary (1961) when he clearly stated that a dictionary should reflect language, not set its style. The descriptive approach was later firmly established during the corpus era with lexicographers relying on real language data to produce dictionaries, like John Sinclair's COBUILD that clearly states its aim as "HELPING LEARNERS WITH REAL ENGLISH".

As is the case with prescription, different types of description can also be distinguished (cf. Bergenholtz 2003). The nature of a descriptive approach determines that a dictionary should not enforce a lexicographer's biased opinion about what belongs in a dictionary or how a specific word should be treated on the users of that dictionary. A dictionary needs to mirror actual language usage and the full spectrum of lexical items should be regarded as potential candidates for a lemma list. The typological classification of a dictionary will determine the nature and extent of items to be included as macrostructural elements as well as their microstructural treatment. Not only the standard variety of a language but all varieties should be considered for lexicographic exposure and where different variants co-occur in the language it needs to be reflected in a dictionary. In this regard the use of a balanced and representative corpus plays an important role in assisting lexicographers to identify their lemma candidates and also the different senses, uses, morphological features, orthographic variants, etc. of a given word in order to ensure a successful descriptive presentation (cf. Tarp and Gouws 2008). A corpus will also indicate the relevant usage frequency and its implications for the lexicographic process.

Having to decide on a prescriptive or a descriptive approach any lexicographer needs to realise that dictionaries are compiled as utility instruments for specific target users with specific needs and reference skills, consulting their 
dictionaries in specific situations of usage. This has to determine each and every aspect of each and every dictionary. Prior to the compilation of a dictionary the lexicographer needs to know what the genuine purpose and the lexicographic functions of the envisaged dictionary will be. The various structures of the dictionary should then ensure that the user will have access to the required data and will be able to achieve an optimal retrieval of information.

\section{The user perspective}

Lexicographers typically work with the assumption that they are familiar with their intended target users and the needs of these users. The dictionary user is no longer the well-known unknown. Questions may be asked regarding the validity of many lexicographers' claims that they know what their users need. The notion of user-friendliness is unfortunately too often determined by the perspective of the lexicographer and not the perspective of the user. An early warning in a comparable regard was formulated by Philip Gove (1966: 183) when speaking about self-explanatory compounds and stressing that the self-in self-explanatory should refer to the interpreter of the word and not the word as such. The decision to include these words in a dictionary should be based on what the user and not the lexicographer will regard as self-explanatory. However, lexicographers usually are spot on when they proclaim that their users want an unambiguous answer to the problem that prompted a specific dictionary consultation. Haas (1967: 48) already maintained: "A good dictionary is one in which you can find the information you are looking for - preferably in the very first place you look." One can add to this that users not only need to find data but they also need to retrieve the relevant and correct information. Owing to different needs of the respective user groups the paraphrase of meaning given for the same word will be different in a general dictionary, a specialised dictionary for lay persons or learners at school and a specialised dictionary for experts. In each case the definition has to be relevant, complete and correct but in terms of the needs and reference skills of the specific target users (cf. Bergenholtz and Gouws 2007).

Average dictionary users see a dictionary as a reference source in which they can find solutions in terms of communication needs, i.e. the text reception, text production and translation functions of the dictionary, as well as cognitive needs, e.g. finding the etymology of a word, an indication of the distance of a marathon or the date of birth of Madonna. They do not want to be confronted with choices but want a straightforward answer to their questions - and the answer must be valid, appropriate, correct and relevant in terms of the type of dictionary and the specific user needs. Where a descriptive approach results in the dictionary offering an unqualified variety of options users become confused and often question the ability of the specific dictionary to be authoritative. Even when the variants have equal status and official recognition users rather prefer to find a single form that can be regarded as the only correct form. To illustrate 
this: the Afrikaans Language Commission, a commission of the South African Academy for Science and Arts officially entrusted with formulating the rules and regulations for Afrikaans orthography, recognised a number of orthographic variants in their official publication the AWS, i.e. the Afrikaanse woordelys en spelreëls (Afrikaans word list and spelling rules). These variants include ver/vêr (far); weereens/weer eens (once again); opheterdaad/op heter daad (redhanded). The AWS is a prescriptive publication presenting the forms acknowledged and prescribed by the Language Commission. However, mother-tongue speakers of Afrikaans consulting this publication as well as dictionaries where these variants are presented often complain that they are looking for a single correct form and do not want a choice between more than one variant. In this regard their ideal dictionary would follow a prescriptive approach by nominating only a single form as the only correct one.

\section{Towards a proscriptive approach}

In the preface to his dictionary, Samuel Johnson said: "every language has ... its improprieties and absurdities, which it is the duty of the lexicographer to correct or proscribe." Since then the word proscribe has acquired term status. In modern-day lexicography, the notion of proscription (from the Latin proscribere - to make public) is introduced in Bergenholtz (2001) and further discussed in, among others, Bergenholtz (2003) and Tarp and Gouws (2008). The characteristic feature of a proscriptive approach is that it offers a presentation, based on a recommendation by the lexicographer. This is not a form prescribed by the lexicographer but recommended by him/her as the preferred form, based on his/her conviction or choice. In some cases of proscription, only a single form is presented, the only recommended form, and in some cases more than one form is presented but accompanied by a clear recommendation by the lexicographer as to the preferred form. Proscription may even see the recommendation of more than one form as being equal. Employing an approach where a recommendation is made, distinguishes proscription from description where variant forms are given without an indication of the preferred form. Where only one form exists, the proscription will not differ from prescription. However, contrary to the strong version of prescription, proscription, even where only a single form is recommended, does not have language purification as its aim but rather a reflection of actual language use. In a certain sense proscription could be seen as the best of both worlds of prescription and description, but it is actually much more radical. In recommending a specific form, the proscribing lexicographer does not have to adhere to the rules or regulations of a normative or prescribing body. The lexicographer may apply his/her own criteria, e.g. general usage frequency or the choice of informed users, to determine the recommended form. It is important that the specific nature of the proscriptive approach employed in a given dictionary, i.e. the motivation for recom- 
mending specific forms, needs to be explained in the users' guidelines text of that dictionary.

Proscription implies a distinction between recommended and non-recommended forms. According to an approach of exclusive proscription only the recommended form will be included in a given dictionary. Contrary to this approach, exact proscription (cf. Bergenholtz 2003: 77) sees the recommendation of only one form but the other variants may be mentioned in the dictionary. Tarp and Gouws (2008) discuss various aspects regarding the implementation of a proscriptive approach, including different ways in which the non-recommended forms can be presented. This regards both the macro- and microstructural representation. On a macrostructural level, the non-recommended lexical items should be included as lemmata that are guiding elements of crossreference articles, referring the user to the article in which the recommended form is given as lemma sign. Such a procedure would ensure that users consulting a dictionary to find a non-recommended form will be guided to the recommended form. However, in terms of the descriptive nature of a proscriptive dictionary and the assignment to reflect actual language use and not only the pure or correct language a dictionary should also inform the user who goes directly to the recommended form of the existence of alternative forms. These forms should also be given in the article of the lemma that represents the recommended form. This can be done in various ways and at present dictionaries actually have two competing ways of presenting variants, with the type of variant determining the article slot where they should be included. Orthographic variants are typically presented in the comment on form, in close vicinity to the lemma sign, cf. the following example from The New Oxford Dictionary of English (NOED):

eirenicon /.../ (also irenicon) ...

The word irenicon has also been included as lemma but with a restricted treatment, indicating to users that this word is "a variant spelling of EIRENICON". This well-established convention of presentation already displays a proscriptive approach with the lexicographer implicitly indicating that eirenicon is the preferred form by allocating the full treatment to this word. By also including the non-recommended variant as a lemma the descriptive component of the proscriptive approach is ascertained. Lexical-semantic variants, e.g. synonyms, are usually presented in a slot in the comment on semantics. In the comprehensive Afrikaans dictionary, the WAT, i.e. Woordeboek van die Afrikaanse Taal (Dictionary of the Afrikaans Language), the lemma katoensnywurm (a certain type of cutworm on cotton plants) receives a full treatment, including a paraphrase of meaning. In the last search zone in the comment on semantics of this article, a listing of synonyms is presented: boor-, klim-, tabak-, snywurm. From this article the user can deduce that katoensnywurm is regarded by the lexicographer as the recommended form but that the other synonyms also prevail as Afrikaans lexical items. By including them the dictionary reflects an aspect of the actual state 
of the lexicon of Afrikaans. Where none of the lexical variants of a recommended form are rejected, the lexicographer should make sure that the proscriptive approach sees the inclusion of these forms not only as individual macrostructural items but also as microstructural items in the article of the lemma sign representing the recommended form, as is the case in the above-mentioned presentation in the WAT. The NOED includes the lemma sign ejector seat but allocates a limited treatment to its article and cross-refers the user to the recommended variant:

ejector seat ... another term for EJECTION SEAT

The article of the lemma sign ejection seat accommodates the full treatment but no indication is given of the variant form ejector seat. This is a less successful form of proscription, i.e. monodirectional proscription.

Besides the distinction between recommended and non-recommended forms, the application of proscription should also take cognisance of the distinction between accepted and rejected non-recommended forms. Where the lexicographer regards a non-recommended form as one that should actually be rejected by the language users the proscriptive approach allows the inclusion of such a rejected form in the dictionary in order to mark the word as a candidate for rejection or to ascertain its disallowance. The HAT, i.e. Verklarende Handwoordeboek van die Afrikaanse Taal (Explanatory Desk Dictionary of the Afrikaans Language) includes the word komper and gives the word rekenaar (computer) as its synonym but complements this restricted treatment with a note indicating that the word komper is not acknowledged by either experts in the field of computers or by the Afrikaans Language Commission. In the article of the lemma sign rekenaar, no reference is made to the non-recommended form komper. The user confronted with the word komper will be able to find the word in the dictionary and obtain the necessary guidance that it is not an acknowledged form along with a reference to the correct or recommended form. The user consulting the dictionary for a retrieval of information regarding the word rekenaar does not need to see the non-allowed form and therefore, contrary to the way in which allowed non-recommended forms are treated, no indication is given of the word komper in the article of the lemma sign rekenaar. Here monodirectional proscription is the acceptable procedure. Including and marking rejected forms is not something new. In his Plan, Samuel Johnson (1747: 29) already said: "Barbarous or impure words and expressions, may be branded with some note of infamy, as they are carefully to be eradicated wherever they are found."

Proscription gives the lexicographer the freedom to recommend one or more forms, to acknowledge those forms that are acceptable albeit that they are not recommended by the lexicographer and to make dictionary users aware of disapproved, rejected or even forbidden forms. Compared to a prescriptive or a descriptive approach, proscription allows a much more balanced reflection of the actual language. 
The macrostructural application of proscription does not only target main lemmata. Sublemmata also fall within its scope. Fixed expressions represent one type of lexical item, typically included as a secondary treatment unit in dictionaries (cf. Potgieter 2008, Gouws To appear). Fixed expressions often have variants and all these variants are not equally acceptable. As an equivalent of the English idiom blood is thicker than water Afrikaans has the expression waar bloed nie kan loop nie, daar kruip dit (literally: blood crawls where it cannot walk). This should be given as the recommended variant but a frequent variant is the direct translation from English bloed is dikker as water. A proscriptive approach should see the inclusion of this variant but as a non-recommended form.

Proscription does not only have lexical items included as treatment units in its scope. Its application can also be directed at microstructural entries presented in the treatment of a given lexical item, e.g. different pronunciation and morphological forms, different uses of a given word, different collocations, etc. The Afrikaans translation of at a stage is in ' $n$ stadium, with the noun stadium collocating with the preposition in. A frequently used but less correct form is the collocation op ' $n$ stadium. In the article of the lemma sign stadium, the co-text slot should include the collocation in ' $n$ stadium, clearly marked in terms of the domestic convention of the specific dictionary as the recommended form, but, in a proscriptive way, the collocation op ' $n$ stadium could also be given as a microstructural entry. A proscriptive approach may merely give the collocation op ' $n$ stadium as an alternative, albeit the non-recommended one. A stronger version of proscription may tend to be more prescriptive by explicitly indicating that the non-recommended form should be forbidden. This is in accordance with a point of view that dictionaries should also guide their users by including as marked entries some disapproved forms.

For a dictionary adhering to a proscriptive approach, it is important that the lexicographers should negotiate the best possible article slot for nonrecommended forms, presented as microstructural entries in the article of a lemma representing a recommended form. By listing the variants in the comment on form in the article slot immediately following the lemma sign or the items presenting grammatical data, the variants occupy a position of salience that might obstruct the rapid inner access that should lead the user to the comment on semantics. Where both orthographic and lexical variants are given in the same article, it could be confusing to enter one type of variant in the comment on form and the other in the comment on semantics. A more acceptable way may be to introduce one article slot dedicated to non-recommended variants. This could be done by employing an extended obligatory microstructure with such an article slot for non-recommended variants given as a final search zone that follows the default article structure. By means of structural indicators, such a search zone should be clearly marked so that it can be easily identifiable as the search zone accommodating non-recommended variants. These variants can be of the lexical item represented by the lemma sign or of 
any other entry presented as microstructural item. Within such a zone for nonrecommended forms provision could be made for different subzones to accommodate the different types of variants. By only accessing the obligatory microstructure, the dictionary seems to follow an approach of exclusive proscription that could easily be regarded as prescription. By merely looking at the slot in the extended obligatory microstructure, the dictionary seems to follow a descriptive approach. Looking at the entire article, one realises that a proscriptive approach has been employed. This type of presentation can enhance the extent of the information transfer that can be achieved in a given dictionary.

\section{Valid applications of a prescriptive approach}

Modern-day lexicographic theory is not prescriptive by imposing one theoretical model on all dictionaries. Different typological categories demand different structures, contents and functions. Similarly the application of procedures of prescription, description and proscription should be determined by the specific dictionary type, the needs of the users and the situation of use.

Within the typological classification of dictionaries, the distinction between LGP dictionaries (language for general purposes) and LSP dictionaries (language for special purposes) has implications for various aspects of the theoretical models. As mentioned before, dictionaries are tools made for the purpose of fulfilling specific user needs (Bergenholtz and Nielsen 2006: 283), and LGP and LSP dictionaries make provision for distinctly different needs. Quite often general dictionaries do include a limited number of terms from specialised fields. This is due to various reasons, e.g. the lack of relevant LSP dictionaries or the need of users of LGP dictionaries to have access to those terms. According to McAdam and Milne (1982), at the time when Johnson compiled his dictionary, technical dictionaries were often more comprehensive and accurate than general dictionaries. Consequently Johnson drew heavily on these dictionaries, e.g. for legal, medical and ecclesiastical terms. Today this still applies in languages with an insufficient typological infrastructure. Access is also needed in general dictionaries to those terms typically used in conversation between the expert and the lay person, e.g. medical or legal terms. In general dictionaries, the treatment of technical terms must ensure an unambiguous retrieval of information and this demands that the paraphrase of meaning is formulated for lay persons and not subject field experts.

Even in LSP dictionaries provision needs to be made for different user groups, with the users being divided into three groups: experts, semi-experts and lay people (cf. Bergenholtz and Tarp 1995 and De Foglio and Lubbe 2002). The expert is usually a subject specialist and is familiar with the terminology. The semi-experts are often students of a subject and have a basic knowledge of the subject and the terminology. The last group, the lay people (who also include translators) often have very little or no knowledge of the subject and the terminology. The expert is someone who might be interested in finding 
variant forms for a given term. A proscriptive approach with a recommended form supplemented by the inclusion of variants will respond to the needs of this expert user. In the Fachwörterbuch zur Lexikographie und Wörterbuchforschung/Dictionary of Lexicography and Dictionary Research currently being compiled the article of the lemma sign Akronymzuordnungsangabe (item relating an acronym to its full form) gets a full treatment, including an article slot, preceded by the non-typographical structural indicator " $="$ in which the lexical variant Kurzwortzuordnungsangabe is given - as a non-recommended but permissible variant. Proscription allows a better data transfer than prescription would have achieved. However, whereas the expert might be interested to find variant forms for a given term the lay person typically needs one form that can be used without the fear of making a mistake. These users need active guidance from the lexicographer telling them that a given word is the appropriate one for a specific technical context. A form of prescription, giving unambiguous guidance with relation to the appropriate, accepted and correct form is needed. This can be done by means of prescription but exclusive proscription could have the same result. This is a section of the lexicographic practice where prescription can be a viable option and it is therefore the one field in modern-day lexicography where lexicographers still often make use of a prescriptive approach in bilingual dictionaries by providing only one translation equivalent for a given word/term. The dictionary user therefore has no trouble deciding on a translation equivalent since the lexicographer has already made the decision. If the lexicographer makes use of a less prescriptive approach and provides a number of translation equivalents in the dictionary article, the experts will usually have sufficient knowledge of the subject field to be able to decide which translation equivalent to choose for a specific text or context. Semiexperts and lay people will however most probably need help in the form of glosses, labels or notes in order to decide on the correct equivalent.

LSP dictionaries do sometimes have a form of descriptive assistance by giving both the British and the American English spelling of a term, but not much more. Once again, for the lay user this may suffice. Experts and semiexperts might need more. This is especially true in LSP dictionaries dealing with terms for which culture-dependent variants occur in the specific language. Sepedi, one of the eleven official languages of South Africa and a member of the Sotho language family, has a range of traditional medical and health care terms. In an LSP dictionary dealing with this field, it is important that the traditional variants should be provided along with the official Western terms. Patients often come to the medical doctor and use the traditional term to explain their problem. As an example: when they have abdominal pain, some Sepedi speakers would say that they have been bitten by a snake. Ignorant doctors had treated such patients with snake bite serum which did not solve the problem. An LSP dictionary of medical and health terms should give the recommended term but also indicate the prevailing variant.

The term prescriptive carries a lot of baggage. Its application does not only 
imply an indication of a single correct form or variant. It also has the connotation of subjectivity, bias and the lexicographer imposing his views and interpretations on the dictionary users. As indicated earlier, proscription can be seen as offering the best features of both prescription and description. Different types of proscription prevail with, for example, exclusive proscription allowing the lexicographer to present only one form without reference to any alternative form. This represents the form recommended by the lexicographer but not on the basis of bias, subjectivity and attempts to purify the language. These issues should in any case not come to the fore in any lexicographic endeavour. Other forms of proscription allow the lexicographer to give a much more comprehensive account of different categories of variants.

\section{In conclusion}

As a dynamic discipline the development of lexicography is characterised by trends and changes. This applies to both the theoretical and the practical component. As an example of trends in theoretical lexicography, one can refer to the shift in research focus from the linguistic contents of dictionaries to the structure of dictionaries and then to lexicographic functions. In the lexicographic practice, one such trend has been the introduction of a corpus-based approach. Johnson's prescriptive approach can be seen as a trend in the lexicographic practice that formed the basis for different realisations and this evolution created the need for a subsequent trend, i.e. the descriptive approach, followed at a later stage by the proscriptive approach. Just as the focus on lexicographic functions does not eschew the value of the linguistic contents of dictionaries or dictionary structures, the proscriptive approach does not imply a total abolishment of prescriptiveness. Although not aiming at fixing the language, a proscriptive approach makes a recommendation to the user and this is typically based on the most appropriate form for a given situation of usage. In addition, the typological expansion in the lexicographic practice resulted in some dictionaries planned and compiled to fulfil a normative assignment which strongly resembles prescription. This is especially true not only in LSP dictionaries where users often are in need of the correct form but also in, for example, school dictionaries where the users need to find the officially recognised and standardised variants of a given language.

By their nature many types of dictionaries can be regarded as normative and they will therefore always maintain some aspects of a prescriptive approach. In order to convey their data in an unbiased way, dictionaries no longer should present the subjective attempts of a lexicographer to purify the language or to portray a specific ideological, religious or political point of view but rather opt for a form recommended on account of its active occurrence in the real language use. In the majority of articles in his dictionary, Samuel Johnson has done exactly that, employing a form of prescriptivism that is today regarded as exclusive proscription. 
Hulbert (1960: xiv) so aptly remarked that "the authority of dictionaries is only that of the men who made them". If that authority is misused to reflect the biased perspective of the dictionary compilers, the prescriptive lexicographer influences language in an unrepresentative way and becomes a harmful drudge. If, however, that authority combines the best of Johnson with Gove's attempts to reflect the real language and the needs of users to find a recommended form representing appropriate and correct language use, the lexicographer gives the intended target users a utility tool that can enhance their communication and cognitive skills.

\section{References}

Bathe, W. 1615. Ianua Linguarum.

Bergenholtz, H. 2001. Proskription, oder: So kann man dem Wörterbuchbenutzer bei Textproduktionsschwierigkeiten am ehesten helfen. Lehr, A. et al. (Eds.). 2002. Sprache im Alltag. Beiträge zu neuen Perspektiven in der Linguistik. Herbert Ernst Wiegand zum 65. Geburtstag gewidmet: 499520. Berlin/New York: de Gruyter.

Bergenholtz, H. 2003. User-oriented Understanding of Descriptive, Proscriptive and Prescriptive Lexicography. Lexikos 13: 65-80.

Bergenholtz, H. and R.H. Gouws. 2007. Korrek, volledig, relevant. Dit is die vraag aan leksikografiese definisies. Tydskrif vir Geesteswetenskappe 47(4): 568-586.

Bergenholtz, H. and S. Nielsen. 2006. Subject-field Components as Integrated Parts of LSP Dictionaries. Terminology 12(2): 281-303.

Bergenholtz, H. and S. Tarp (Eds.). 1995. Manual of Specialised Lexicography: The Preparation of Specialised Dictionaries. Amsterdam/Philadelphia: John Benjamins.

Botha, W.F. et al. (Eds.). 1951-. Woordeboek van die Afrikaanse Taal. Stellenbosch: Buro van die WAT.

Cawdrey, R. 1604. A Table Alphabeticall. London: E. Weaver.

Changuion, A.N.E. 1844. Proeve van Kaapsch Taaleigen. Changuion, A.N.E. 1844. De Nederduitsche Taal in Zuid-Afrika hersteld. Cape Town: J.H. Collard.

Chesterfield, Lord. 1754. Letter to The World.

De Foglio, F. en H.J. Lubbe. 2002. 'n Praktiese benadering tot die samestelling van 'n tweerigtingvakwoordeboek met Afrikaans en Italiaans as taalpaar. Lexikos 12: 117-132.

Gouws, R.H. To appear. Fixed Word Combinations as Second Level Treatment Units in Dictionaries. Ďurčo, Peter (Ed.). To appear. Proceedings: International Colloquium on Lexicography, Bratislava, 2008.

Gove, P.B. 1966. Self-explanatory Words. American Speech 41: 182-198.

Gove, P.B. (Ed.). 1961. Webster's Third New International Dictionary of the English Language. Springfield, Mass.: Merriam-Webster.

Haas, M.R. 1967. What Belongs in a Bilingual Dictionary? Householder, F.W. and S. Saporta (Eds.). 1967. Problems in Lexicography: 45-50. Bloomington: Indiana University.

Hulbert, J.R. 1960. Dictionaries: British and American. Second Edition. London: André Deutsch.

Johnson, S. 1747. The Plan of a Dictionary of the English Language. Facsimile Edition 1970. Menston: The Scholar Press. 
Johnson, S. 1755. A Dictionary of the English Language. London: J. \& P. Knapton/T. \& T. Longman et al.

Komensky, A. 1631. Ianua Linguarum Reserata.

McAdam, E.L. and G. Milne. 1982. Johnson's Dictionary. A Modern Selection. London: Papermac.

Odendal, F.F. and R.H. Gouws. 2005. Verklarende Handwoordeboek van die Afrikaanse Taal. Fifth Edition. Cape Town: Pearson Education.

Pearsall, J. (Ed.). 1998. The New Oxford Dictionary of English. Oxford: Oxford University Press.

Potgieter, L. 2008. ' $n$ Moontlike model vir die bewerking van idiome in tweetalige woordeboeke. Lexikos 18: 190-206.

Sinclair, J. (Ed.). 1988. Collins COBUILD English Language Dictionary. London: HarperCollins.

Tarp, S. and R.H. Gouws. 2008. A Lexicographic Approach to Language Policy and Recommendations for Future Dictionaries. Lexikos 18: 232-255.

Taalkommisie van die S.A. Akademie vir Wetenskap en Kuns. 2001. Afrikaanse Woordelys en Spelreëls. Cape Town: Pharos.

Wiegand, H.E. (Ed.). 2010. Fachwörterbuch zur Lexikographie und Wörterbuchforschung/Dictionary of Lexicography and Dictionary Research. Berlin: de Gruyter. 